日臨外会誌 $49(7), 1188-1192,1988$

原著

\title{
抗癌剂動注と局所温熱併用の肝癌縮小効果
}

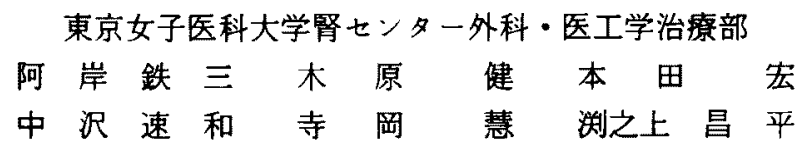

植え込み型カテーテルンステムである vascular access device からの選択的抗癌剂動 注と RF 波発信による局所温熱の併用により22名の手術不能肝癌患者を治療した結果を 報告した。

MR 以上 $77.2 \% ， \mathrm{PR}$ 以上 $45.5 \%$ という癌粳小奻果が得られた。

さらに,この治療法導入初期に活性炭血液潅流下に抗癌剂大量動注を行った症例では， MR 以上 $83.3 \% ， P R$ 以上 $50.0 \%$ という高い有効性が得られた。

重篤な合併症は認められなかった。

高浱度抗癌剂動注と局所温熱の相乗効果を期待できる方法と考えられ，積極的な適用 が勧められる。

柬引用語：抗癌凨動注，局所温熟，制癌効果

はじめに

悪性尰瘍に対する治療成績は，近年向上しつつある のは事実であるが，成䋶向上の要因としては治㞠法そ のものより各種診断技術の進歩によって早期診断が可 能となり，手術的治療の早期開始ができるよ5になっ たことが指摘される。一方，手術的治㞠の時期をこえ た癌・再発癌に対する従来の方法による治療成績は相 変わらす極めて悪く，MR 以上の癌樎小奻果が得られ るのは，たかたか症例の $20 \%$ 程度といらのが一般的で ある.

これに対して，最近は，いわ少学的治療 (multidisciplinary treatment)が行われるよ5kなっ ている. 集学的といら用語が医学の中での外科学・内 科学・薬理学・放射線医学などの総合を意味するのか， 医学以外の工学・理学などの応用を意味するのか不明 確であるが，ここでは，その両方を含むるのとして用 いることとする。

一方, 疾患として異常を持つ贜器・組織に対して選 択的に治療を行らことの優位性から標的治㞠（targeted treatment）が考光られ, 各種の手段が案出されて いる".

ここでは，両者の考えをとりいれた植え込み型か

昭和 62 年 10 月 26 日受付 63 年 4 月 15 日採用
テーテルからの肝動脈内への抗癌剤注入療法と RF 波 放射による局所温熱療法との併用効果についてて報告す る.

\section{1. 患者}

万 法

治療の対象となったのは，他医によって手術的治療 の段階を越えたと判断され紹介されてきた22名の肝癌 患者である.内訳は, 原発性肝癌 7 名(17歳加ら74歳， 平均 52.5 歳) ・転移性肝癌 15 名 (27藏から75藏, 平均 55.8歳）である.

\section{2. 手段・治癔機器}

1）動注療法：動注療法は, 植之込み型カテーテルシ ステムである vascular access device (Vascular Access Port, Norfolk 社, U.S.A., Catheter Access, ニブロ医工，大阪，またはInfusaid，東機貿，東京） を通じて，経皮的穿刺によって行った233.

Vascular access device の植光込みは，初期にはシ ステム全体を手術的に，例えば肝動脈に対して開腹下 に直接的にカテーテルを挿入し、リザーバを皮下組織 内に留置するよらな方法によったが，最近では Seldinger 法に準じてカテーテルを目的とする肝動脈内に経 皮的操作によって择入・留置し, vascular access deviceのリザーパの部分のみを手術的に皮下組織内 に植え込んで接続する方法を採用している゙，リザー 
淍辺皮下組織の手術操作による变化が修復される術 後 1 週間目位から実際に抗癌隹注入を開始する。

Vascular Access Port および Catheter Accessは, 元来 one shot 用の薬物注入口として作られたもので あるが，擭帯型の小型ポンブと経皮的穿刺針によって 連結すると, Infusaid 同様, 薬剂の持続的注入口とし ても使用できる。

抗癌剤の動注は，原則的に局所温熱下に行った。 抗癌凪としては，通常の one shotには，主として 6 10mg の mitomycin C, 50mg の adriamycin また は50mgの cisplatinを，持続動注には，主として250 mg/日の5-fluorouracil を用いた, one shot 動注の場合 には、ほかに150〜300mg/日の5-fluorouracil, 3.0g/日 の crestinなどの服用を併用した。

またこの治療の導入期には，患者の全身状態が許 せば1.0〜1.5mg/kgの mitomycin C, あるいは $100-150 \mathrm{mg} \omega$ adriamycin $の$ one shot 動注を積極的 に行ったが，この揚合には末梢循環血中の抗癌風を急 速に除去するため，活性炭吸着筒による吸着剂血液潅 流を 3 時間同時に行っだ'6)。

2）局所温熱：初期には ThermaTech 2000 (International Institute for Medical Science, U.S.A.) を, 中期以降は Novatherm (Internova，東京)を用いて いる.これらの装置は，一対の applicator の間に13.56 $\mathrm{MHz}$ の RF 波を発信し, 局所深部温度を $42 \sim 43^{\circ} \mathrm{C}$ で加熱させることが報告されている7゙8).

この治療は，治療導入の初期のみ入院中に行い，以 後は外来的に行らことを原則としたので，温度セン サ一穿刺に上る睡瘍内温度测定は毎回は行わず，いる いろな状況が整ったときに行った温度剆定時の加温条 件をくりがすこととした。

温度療法は, 通常週 1 ～2回， 1 ～ 3 時間行らこと
とした.

\section{結果}

多くの患者で温熱療法の開始後に肝搭の位着に相当 する右上腹部の王迫・畽脹感の軽快などの臨床的に好 ましい効果が得られた，典型的な場合には，初回の温 熱療法時から加温されている局所が心地よく，2-3 日の間に局所に明らかに軽くなる感じが現われる。し かし，導入期に大量動注を行ったよ5な患者では，4 〜5日中に右上腹部を中心として全身に払がる $38 \sim 39^{\circ} \mathrm{C}$ 発熱がある. 腫煬の壊死とその後の吸収に よる発熱と考えられる。この時期が過ぎると，楥解期 になる。

しかし，患者の自覚症状では効果の評価が難しいの で, computerized tomography による治療標的とした 隀場の大きさ(長径入短佳)の变化で評価した結果を 報告することとする（表 1 ，図 1，図 2 ）。

この併用療法によって MR 以上 $(M R+P R+C R) の$ 効果が得られたのは，22例中17例 (77.2\%)に達した。 $\mathrm{PR}$ 以上（PR+CR）にしぼると22例中10例（45.5\%） に効果が得られた。

特に，導入初期に抗癌風の大量動注と活性炭の血液 潅流とを併用した群では，MR以上が18例中15例 $(83.3 \%)$ ，PR 以上て 18 例中 9 例 $(50.0 \%)$ とい5高い 有効性が得られた。

一方，大量動注を行わずに治療を開始した群では， MR 以上か: 4 例中 2 例 $(50.0 \%)$, PR 以上では 4 例中 1 例 $(25.0 \%)$ にととまった。

生化学的バラーターでは，転移性訮癌に拈ける CEA 值の変動が腫湯の大きさの変化とよく相関する 傾向があり，畽海の粨小が著明な場合にはCEA 值は 降下し，腫湯サイズの増大が再び認められるようにな ると，CEA 值は著しく上年する傾向が認められた。

表 1 肝蕰に対する局所温熱と抗癌部投与との併用療法の効果

\begin{tabular}{|c|c|c|c|c|c|c|c|}
\hline & $\mathrm{CR}$ & PR & MR & NC & PD & NE & 総計 \\
\hline 局所温熱のみ & & & 1 & 7 & & & 8 \\
\hline 局所温熱十常用量觧注 & & 1 & & 11 & 1 & 4 & 17 \\
\hline 局所温熱＋間矢的常用量動注 & & 1 & & 1 & & & 2 \\
\hline 局所温熱＋持続的常用量動注 & & & 1 & 1 & & & 2 \\
\hline 局所温熱＋大量動注＋間欠的常用量動注 & 1 & 4 & 4 & 2 & 1 & & 12 \\
\hline 局所温熱＋大量動注＋持続的常用量動注 & & 4 & 2 & & & & 6 \\
\hline 総 & 1 & 9 & 7 & 4 & 1 & & 22 \\
\hline
\end{tabular}




\section{$11-19-85$}

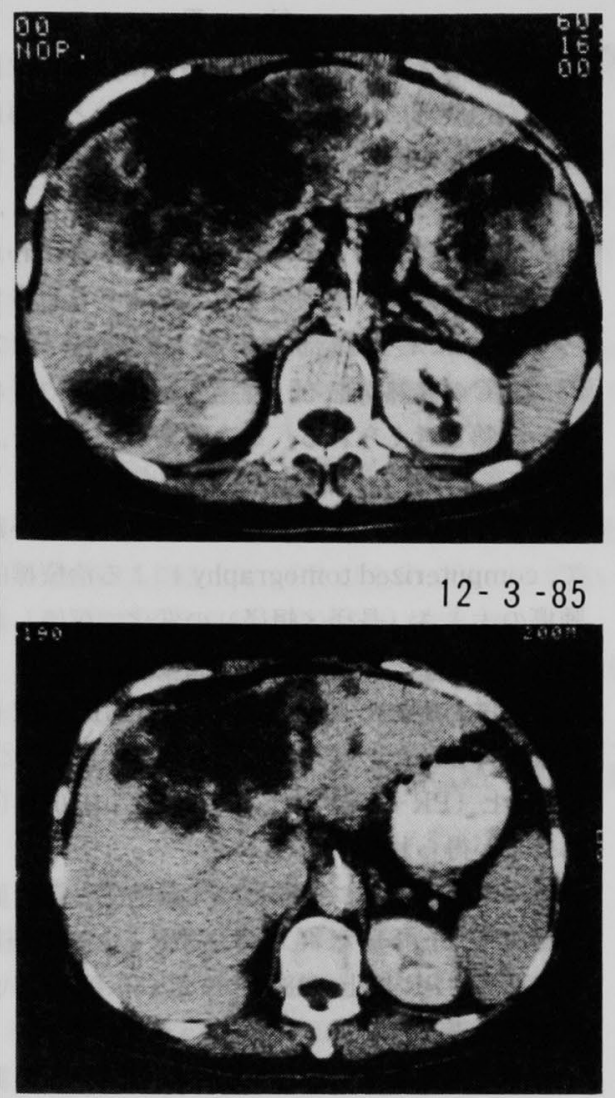

\section{F.M. 64 y.o. female Hepatoma}

図 1 患者の CT 像の典型的変化 ( 1 )：11-19-85に行われた大量動注を主体とする温 熱化学療法によって, 右葉腹側部の大きな腫埸は著明に減少し, 右葉背側部の腫湯 はCT 上指摘できなくなった。

\section{考 察}

植え込み型カテーテルの使用は, 欧米ではここ数年 間に爆発的に増えて来つつある。すでに，ヨーロッハ では 6 社から、アメリカでは 5 社から vascular access device が発売されている. しかし, 欧米ではこの vascular access device は採血と輸液の目的で静脈内に留 置使用されることが多く，抗癌凨などの動注に使用さ れるのは $20 \%$ 程度とされている，わが国では，現在の 所，ほとんどが抗癌剤動注を目的として植え込まれて いるようである。

Vascular access device からの抗癌剤選択的動注と RF 波による局所温熱とは, 全く別のグループの医師 たちによって治療して行われているのが現状であり， 局所加温下に抗癌剂の大量動注と活性㞸血液潅流とを 組み合わせた報告はこれまでにない。
この方法による臨床的有効度は，先に述べたように 導入期に大量動注を行った場合には，MR以上で 83.3\%, PR 以上で50.0\%とい5高率であった。大量動 注を行わずに，通常量動注たけで治療した場合を含め ても, MR 以上で $77.2 \%, P R$ 以上で $45.5 \%$ とい5有奻 度が得られた，進行肝癌に対する従来の治療法による 有効度が，20\%程度であることからこの方法の臨床的 有用性を強調することができる91101.なお，われわれの 経験でも局所温熱療法のみでは, MR 以上の有効性が 認められたのは 8 例中 1 例 $(12.5 \%)$, 局所温熱に抗癌 剂静注を併用した場合で，MR 以上の有効性が認めら れたのは17例中 1 例 (5.9\%) であったので，選択的動 注療法の有用性が確認された。

ここで報告した方法は，いくつかの手段を組み合わ せたものであり，そのおのおのは安全性の高い医㞠手 


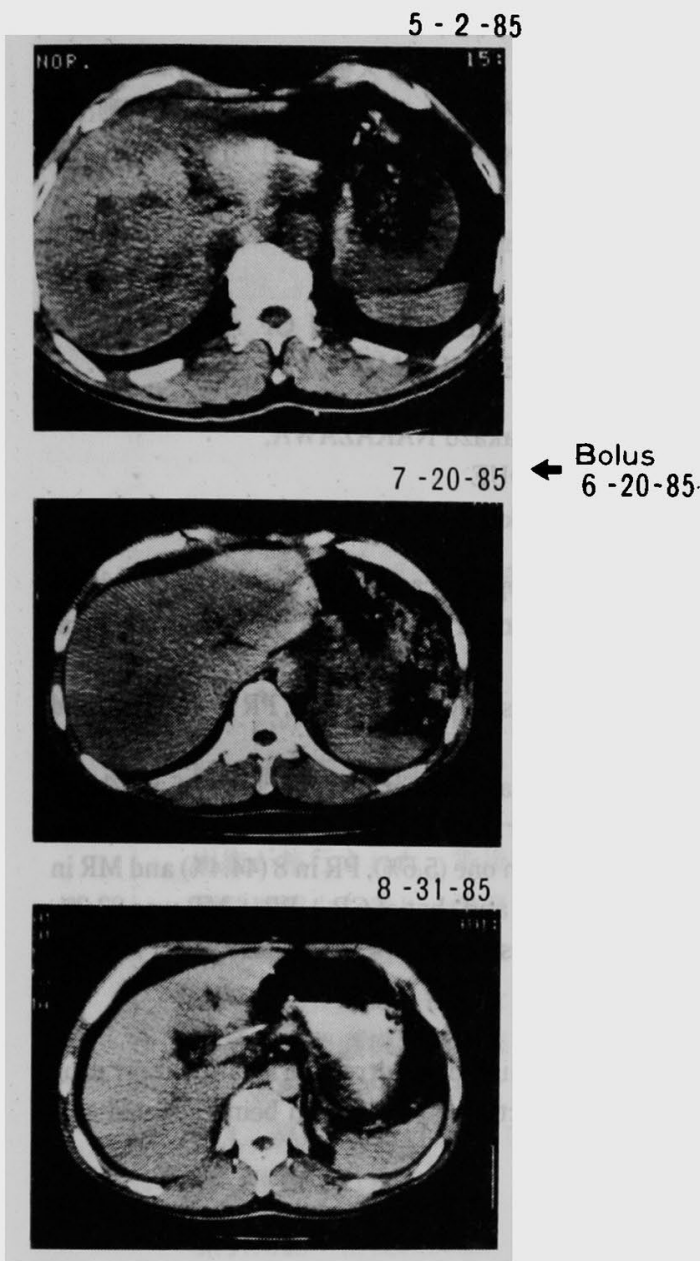

図 2 患者の CT 像の典型的変化 ( 2 )：転移性の多発 性尰瘍は 6-20-85に行われた大量動这を主体とする 温熱化学療法によって次第に縮小し，8-31-85には CT 上確認できなくなった。

段としてほぼ確立されたものばかりであるといえる か，可能性のある問題点について考えてみる.

1. vascular access device からの動注 カテーテルの肝動脈内への挿入・留置は最近では, 第一選択として Seldinger 法に準じて行っている，患 者に対する侵襲が，手術法に比べてはるかに軽微であ るからである。

カテーテルの開存性はよく，本田らの報告による そ11) 2 週から29カ月にわたる30例の追跡調査で, 閉塞 は3例にみられたたけで，それも定期的な薬片注入 ・ へバリン加生理的食塩水の注入を行わなかった患者た けであった，血栓形成による下肢梗塞などが臨床的に
問題となったことはない。

胃十二指腸動脈内一の抗癌剂注入に由来することも 疑われた十二指腸潰瘍は，保存的治療により治瘾した。

\section{2. 局所温熱}

局所温熱は，きわめて安全な医療である，2 例にお いて，II度の熱傷が生じたか，温熱を一時的に中断す ることにより数週以内に治瘳した。

3. 抗菭郕大量動注と活性炭血液潅流による急速除 去

白血球減少症 $\left(\mathrm{WBC}<3,000 / \mathrm{mm}^{3}\right)$ か 6 例に見ら れ, 血小板减少症 (Thrombocyte $<75,000 / \mathrm{mm}^{3}$ ) かi 8 例に見られたが程過を観察する中に数週以内に正常化 した。軽度の肝機能障害 (GOT, GOP $>100 \mathrm{KU})$ が 3 例に見られたが，保存的に対処し得た。頭髮の脱毛が， 3 例に起こったが数週以内に元に復した。

\section{文献}

1) 桜井靖久, 金井達明, 阿岸鉄三他：標的治療技術, BME 1:580-627, 1987

2) Gyves JW, Ensminger WD, Niederhuber JE, et al : A totally implanted injection port system for blood sampling and chemotherapy administration. JAMA 251 : 2538-2541, 1984

3）洴上昌平，寺岡慧，阿岸鉄三他：Vascular access port の使用経験, 人工缄器 $14: 1045$ $-1048,1985$

4) 本田 宏, 阿岸鉄三, 大場 忍他：抗癌剂動注用植 え込み型カテーテルの留置法一開腹手術か, 血管 造影手技か?一,癌と化療 $14: 2359-2363,1987$

5) 阿岸鉄三, 山縣 淳, 奥村俊子他：制癌㓮大量投与 と血液浄化法による急速除去, 臨泌 $35 ： 249$ $-254,1981$

6) Yamagata J, Agishi $T$, Okumura $T$, et al : Administration of anticancer agent in combina. tion with hemoperfusion over charcoal. Trans Amer Soc Artif Intern Organs 27 : 532-534, 1981

7）光野貫一，阿岸鉄三，中沢速和他：局所温熱療法装 置 Therma Tech 2000 の使用経験, 癌と化療 12: 1099-1104, 1985

8) Mitsuno K, Agishi $T$, Okumura $T$, et al : Local hyperthermia in combination with mild general hyperthermia by injection of pyrogenic-immunopotentiating agent for cancer treatment. Hyperthermic Oncology 1984 : $265-268,1984$ 
9）中沢速和，阿岸鉄三，奥村捘子他：制癌剂選択大量

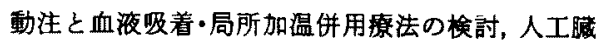
器 $15: 443-446,1986$

10）阿岸鉄三，中沢速和，寺岡 慧他：Vascular access port からの制癌郕選択的動注之局所温熱
療法の併用効果，癌と化療 $13 ： 502-507 ， 1986$

11）本田 宏, 阿岸鉄三，大場 忍他：進行癌患者に対 する植え込み型カテーテルを用いた抗癌郕動注療 法，日臨外会誌 $49: 936-941 ， 1988$

\section{REDUCTION IN SIZE OF HEPATIC CARCINOMAS BY INTRAARTERIAL INFUSION OF ANTICANCER DRUGS IN COMBINATION WITH LOCAL HYPERTHERMIA}

Tetsuzo AGISHI, Takeshi KIHARA, Hiroshi HONDA, Hayakazu NAKAZAWA,

Satoshi TERAOKA and Shohei FUCHINOUE

Department of Surgery and Therapeutic Engineering, Kidney Center, Tokyo Women's Medical College

Twenty-two patients who had been diagnosed as having inoperable hepatic carcinoma were treated with a combination of an intraarterial anticancer drug administered via an implanted vascular access device and local hyperthermia given by a $13.56 \mathrm{MHz}$ radiofrequency wave.

Tumor reduction as assessed by computerized tomography was as follows: $C R$ in one (4.5\%), $P R$ in 9 (40.9\%) and MR in 7 cases (31.8\%).

Eighteen of the 22 patients were specially treated with a high dose of anticancer drugs (1.0 to $1.5 \mathrm{mg} / \mathrm{kg}$ of mitomycin $\mathrm{C}$ or 100 to $150 \mathrm{mg}$ of adriamycin) injected in a one-shot manner under charcoal hemoperfusion at an initial stage of the treatment. Tumor reduction was even more marked: $C R$ in one (5.6\%), PR in 8(44.4\%) and MR in 6 cases $(33.3 \%$ ). In other words, the effectiveness ratio of $C R+P R$ was $50.0 \%$, and that of $C R+P R+M R$ was $83.3 \%$. This is an extraordinarily high level of effectiveness compared with usual results of $20 \%$ to $30 \%$ for $C R+P R+M R$ obtained by conventional regimens.

No serious complications were observed.

In conclusion, a novel multidisciplinary treatment modality applying a high-dose intraarterial anticancer drug combined with local hyperthermia resulted in unusually good tumor reduction and is worth being adopted as a treatment for inoperable cancer in other organs. 